\title{
PERBANDINGAN PRESTASI BELAJAR SISWA SISTEM FULL DAY SCHOOL DAN SISTEM REGULER KELAS IV SEKOLAH DASAR TAHUN AJARAN 2019/2020 DI KECAMATAN KEBUMEN
}

\author{
Afrida Conniestia Ikhsani, Suhartono, Ratna Hidayah \\ Universitas Sebelas Maret \\ afridaconnie@student.uns.ac.id
}

\section{Article History \\ accepted 01/10/2020}

approved 01/11/2020 published 01/12/2020

\begin{abstract}
The education system in Indonesia is divided into two types, namely the education full-day school system and the regular system. These two systems have differences in the length of study time, the emotional level of students, and the fatigue of students. The fatigue will greatly affect students in terms of learning which will also affect the level of student achievement during school. The study aimed to explain the differences between full-day school system and regular system on student learning achievement to fourth grade of elementary school. It used comparative quantitative research methods. Data collection techniques were observation and tests. Data analysis used test Independent Sample T-test. The result of the research indicated that there were differences between full-day school system and regular system on student learning achievement to fourth grade of elementary school in Kebumen sub-districts in academic year of 2019/2020. The Sig value on the independent sample t-test was 0.034 . It meant that Sig value was $0.000<0.05$ (level 5\%) thus it rejected $H_{0}$. The averages of student learning achievement of fourth grade were 8.5867 in regular system and 8.3685 in full-day school system.
\end{abstract}

Keyword: learning achievement, regular system, full-day school system

Abstrak : Sistem pendidikan di Indonesia dibagi menjadi dua macam yakni sistem pendidikan full day school dan sistem reguler. Kedua sistem ini memiliki perbedaan lama waktu belajar, tingkat emosional siswa dan kelelahan pada siswa. Kelelahan pada siswa ini akan sangat memengaruhi siswa dalam hal cara belajar yang nantinya juga akan memengaruhi tingkat prestasi siswa selama sekolah. Penelitian ini bertujuan untuk menjelaskan perbedaan antara Prestasi Belajar Siswa Sistem Full Day School dan Siswa Sistem Reguler Kelas IV Sekolah Dasar. Penelitian ini menggunakan metode penelitian kuantitatif komparatif. Teknik pengumpulan data berupa observasi dan tes. Analisis data menggunakan uji Independent Sample T-tes. Hasil penelitian ini menunjukkan terdapat perbedaan prestasi belajar antara siswa yang bersekolah di sekolah dengan sistem reguler dengan siswa sistem full day school kelas IV Sekolah Dasar tahun ajaran 2019/2020 di Kecamatan Kebumen. Nilai Sig. pada uji independent sample $t$-test yaitu 0,034 yang berarti bahwa nilai Sig. 0,000 0,05 (taraf $5 \%$ ) sehingga tolak $\mathrm{H}_{0}$. Rata-rata prestasi belajar siswa kelas IV sekolah dasar adalah 8,5867 untuk sistem reguler dan 8,3685 pada siswa sistem full day school.

Kata kunci: Prestasi belajar, sistem reguler, sistem full day school 


\section{PENDAHULUAN.}

Peningkatan kualitas pendidikan dapat terlihat dari peningkatan prestasi akademik. Prestasi akademik disebut juga dengan prestasi belajar, menurut Suryabrata (Ernita, Fatimah, Adawiyah, 2016: 973), prestasi belajar adalah perumusan akhir berupa nilai yang diberikan oleh guru kepada siswa mengenai peningkatan kemampuan belajar yang dicapai oleh siswa selama waktu tertentu. Untuk meningkatkan prestasi belajar ini, diperlukan proses kegiatan belajar mengajar yang baik dan sesuai dengan tingkat karakteristik siswa. Pelaksanaan program pembelajaran ini tidak lepas dari peran lembaga penyelenggara pendidikan yang masing-masing memiliki sebuah sistem dalam menjalankan kegiatan pembelajaran.

Sistem pendidikan di Indonesia dibagi menjadi dua macam yakni sistem pendidikan full day school dan sistem reguler, (Hakim dan Prameswari dalam Irayasa dkk, 2018: 79). Pembelajaran dalam pendidikan sistem reguler menggunakan kelas yang bersifat umum digunakan oleh sekolah-sekolah dengan sistem yang tetap atau biasa, maksudnya pada sistem reguler ini guru memberikan materi pada siswa dengan menggunakan metode atau model pembelajaran yang biasa dan cenderung tidak memiliki program-program khusus yang membuatnya nampak berbeda dengan sekolah lain (Mukhromah, 2017: 62), sedangkan sistem full day school dijelaskan menurut Sismanto (Sari, 2018: 67) full day school yakni suatu model sekolah umum yang memadupadankan sistem pembelajaran islam maupun umum yang dilakukan secara intensif melalui penambahan waktu khusus untuk lebih memperdalam keagaman atau materi pengetahuan. Hakim dan Prameswari (Irayasa dkk, 2018: 79) berpendapat bahwa perbedaan yang mendasar dari sistem reguler dan full day school ini yaitu pada lama waktu belajar. Menurut Utomo (Irayasa, dkk, 2018: 79) full day school dapat diartikan sebagai sekolah yang menerapkan atau menggunakan sistem pembelajaran sehari penuh atau berlangsung dari pagi hingga sore hari. Perbedaan yang berarti antara sistem reguler dan full day school terlihat dari lama waktu belajar yang nantinya sangat berpengaruh terhadap hasil belajar siswanya.

Penerapan full day school pada hakikatnya memiliki tujuan secara holistik sesuai dengan pendapat Hasan (Winarni, 2015: 2) bahwa tujuan full day school yaitu untuk mengembangkan seluruh potensi siswa agarmenjadilebih baik dan seimbang sehingga nantinya siswa dapat memiliki kemampuan dari segi kognitif, afektif dan psikomotor yang baik. Namun dalam perkembangannya, menurut Hadiwidjojo (Syam, 2017) pelaksanaan full day school memunculkan beberapa kasus seperti kelelahan, stres hingga gangguan emosi pada anak sampai menolak untuk sekolah atau mogok sekolah. Tingkat kelelahan pada siswa yang bersekolah di sekolah dengan sistem full day lebih tinggi dibandingkan siswa sekolah reguler, hal tersebut juga dapat berpengaruh terhadap tingkat emosional siswa. Tingkat emosional siswa full day school lebih tinggi dari siswa sekolah reguler dikarenakan siswa full day school mengalami pembelajaran yang cukup lama hingga dapat memicu stres pada siswa.

Pandangan inilah yang mengakitbatkan ketimpangan antara sistem reguler dan full day school. Selain itu terdapat pula perbedaan dari segi rata-rata hasil prestasi belajar sistem reguler dan sistem full day school. Prestasi belajar siswa sekolah reguler lebih tinggi dari siswa sistem full day school, dengan nilai 72,24 pada sekolah full day school dan 88,16 pada sekolah regular, (Irayasa, dkk, 2018: 84). Sedangkan Panji (2016: 14) berpendapat bahwa nilai rata-rata siswa program khusus (full day school) mencapai 3,44 dan pada kelas program reguler mendapatkan nilai rata-rata sebesar 3,32. Hal tersebut menjelaskan bahwa prestasi belajar siswa program atau sistem full day school lebih tinggi dibanding dengan siswa program regular. Perbedaan ini dikarenakan penelitian tersebut hanya mengkaji prestasi belajar siswa dari satu mata pelajaran saja. 
Dari pernyataan di atas peneliti ingin mengkaji mengenai perbedaan prestasi siswa pada sistem full day school dan siswa pada sekolah sistem regular dengan membandingkan prestasi belajar siswa dari beberapa mata pelajaran dalam pelajaran tematik. Oleh karena itu peneliti membuat penelitian dengan judul "Perbandingan Prestasi Belajar Siswa Sistem Full Day School dan Siswa Sistem Regular Pada Siswa Kelas IV Sekolah Dasar di Kecamatan Kebumen Kabupaten Kebumen Tahun Ajaran 2019/2020.

\section{METODE}

Penelitian ini merupakan jenis penelitian kuantitatif dengan menggunakan metode kuantitatif komparatif. Metode ini dipergunakan karena penelitian ini berusaha untuk menemukan ada tidaknya perbedaan prestasi belajar siswa sistem full day school dan sistem reguler siswa kelas IV sekolah dasar. Populasi pada penelitian ini yaitu semua siswa kelas IV SD se-Kecamatan Kebumen. Populasi dalam penelitian ini bersifat homogen, dilihat dari peringkat nilai UN di Kecamatan Kebumen maka teknik pengambilan sampelnya menggunakan non probability sampling dengan menggunakan teknik purposive sampling. Sampel dalam penelitian ini adalah siswa kelas IV Sekolah Dasar di Kecamatan Kebumen yang diambil dari 2 SD yaitu SD Islam Ulil Albab dan SD Negeri 1 Kutosari. Kedua Sekolah ini memiliki akreditasi yang sama yaitu A. Adapun jumlah sampel dalam penelitian ini adalah 66 siswa.

Teknik pengumpulan data dalam penelitian ini menggunakan observasi dan tes. Observasi dilakukan untuk mengamati proses pembelajaran yang mencakup komponen pembelajaran, sedangkan tes digunakan untuk mengukur tingkat prestasi belajar siswa secara kognitif. Instrumen tes diuji validitas dan reliabilitasnya terlebih dahulu. di SDN 1 Kebumen dan SDIT Al- Madinah di Kecamatan Kebumen.

Peneliti menggunakan aplikasi SPSS versi 16.0 dalam menguji hipotesis. Uji persyaratan analisis data pada penelitian ini yaitu uji normalitas dan uji homogenitas. Selanjutnya uji analisis data menggunakan Uji Independent sample t-test.

\section{HASIL DAN PEMBAHASAN \\ Hasil Observasi Pembelajaran Sekolah Reguler dan Full Day School}

Penelitian ini menggunakan metode observasi (pengamatan) pada pembelajaran di sekolah reguler maupun full day school. Pengukuran dalam Observasi pembelajaran menggunakan lembar pengamatan dengan menyesuaikan standar komponen pembelajaran yakni: 1) Tujuan pembelajaran, 2) Materi ajar, 3) Metode pembelajaran, 4) Media pembelajaran dan 5) Evaluasi, (Ngalimun, dkk, 2016: 40). Hasil pengamatan pembelajaran pada sekolah full day pada pertemuan pertama didapatkan skor 38 termasuk dalam kriteria C (cukup), kemudian terdapat beberapa inovasi dalam metode pembelajaran sehingga pada pertemuan kedua meningkat menjadi B (baik) dengan total skor 42, begitu pula pada pertemuan ketiga dengan total skor 44 termasuk dalam kriteria B (baik), sedangkan pada sekolah reguler pada pertemuan pertama dengan total skor 42 termasuk dalam kriteria B (baik), lalu pada pertemuan kedua dan ketiga terdapat peningkatan menjadi kriteria $A$ (sangat baik) dengan total skor pertemuan kedua 50 dan pertemuan ketiga 52. Dari hasil tersebut sekolah reguler memiliki skor yang lebih tinggi dibanding sekolah full day.

\section{Deskripsi Data}

Penelitian dilakukan dengan memberikan tes prestasi belajar. Sebelum dianalisis , data harus melalui proses deskriptif menggunakan aplikasi SPSS versi 16.0 berikut adalah data penelitian yang diperoleh: 


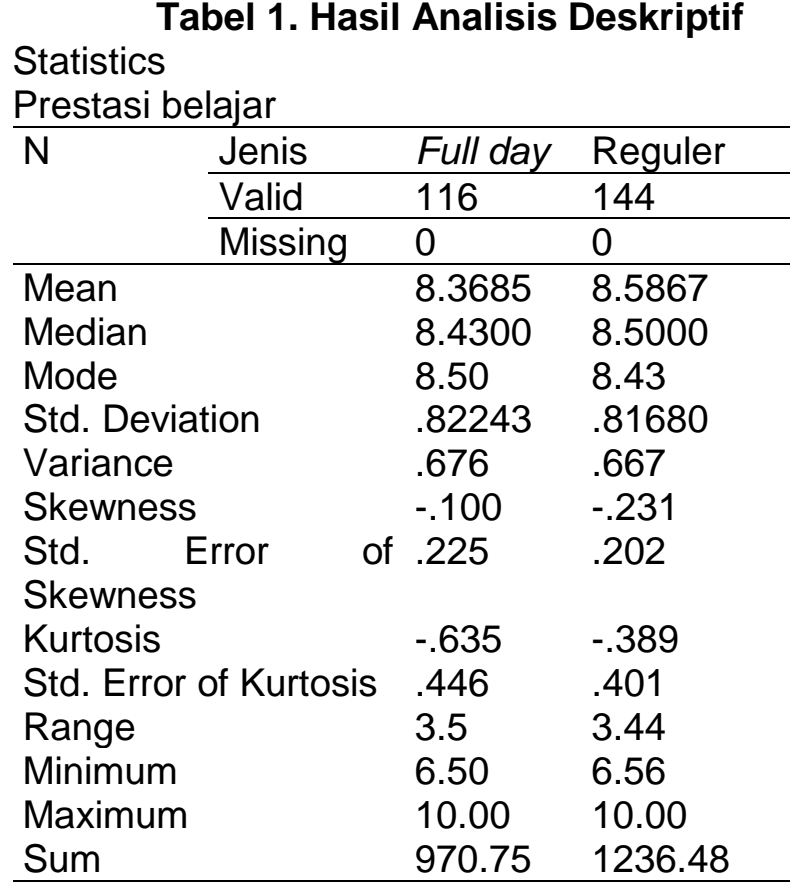

Dari data diatas menjelaskan bahwa keduanya memiliki data berdistribusi normal dengan jumlah rata-rata nilai prestasi belajar 116 siswa full day school yang menjadi sampel penelitian yaitu 970,75. Jumlah rata-rata nilai prestasi belajar 144 siswa reguler yang menjadi sampel penelitian yaitu 1236,48. Jumlah rata-rata siswa reguler lebih tinggi dibandingkan dengan siswa full day.

\section{Uji Persyaratan Analisis}

Uji prasyarat analisis dilakukan sebagai syarat sebelum melakukan pengujian hipotesis penelitian tehnik Uji Independent sample t-test. Uji prasyarat data pada penelitian ini telah terpenuhi yaitu data berdistribusi normal dan data homogen. Prestasi belajar siswa sekolah reguler berdistribusi normal ditunjukkan dengan nilai signifikasi 0,200 dan prestasi belajar siswa full day school berdistribusi normal dengan nilai signifikansi sebesar 0,198 . Nilai signifikansi tersebut menunjukkan signifikansi > 0,05 sehingga data berdistribusi normal. Setelah variabel bedistribusi normal selanjutnya dilakukan uji homogenitas. Data pada penelitian ini berasal dari populasi homogen, hal tersebut ditunjukkan dari nilai signifikasi sebesar 0,911. Nilai signifikasi > 0,05 sehingga data hasil prestasi belajar siswa sekolah reguler dan full day school merupakan data yang homogen.

\section{Uji Hipotesis}

Pengujian hipotesis dalam penelitian ini menggunakan Uji Independent sample t-test.

Tabel 2. Output Pertama Hasil Analisis Uji Independent Sample T-Test

\section{Group Statistics}

\begin{tabular}{cccccc}
\hline & $\begin{array}{c}\text { Jenis } \\
\text { Sistem }\end{array}$ & $\mathbf{N}$ & Mean & $\begin{array}{c}\text { Std. } \\
\text { Deviation }\end{array}$ & $\begin{array}{c}\text { Std. Error } \\
\text { Mean }\end{array}$ \\
\hline Prestasi & Reguler & 144 & 8.5867 & .81680 & .06807 \\
Belajar & Full day school & 116 & 8.3685 & .82243 & .07636 \\
\hline
\end{tabular}

Output ini menjelaskan tentang statistik antara prestasi belajar siswa yang bersekolah di sekolah reguler dengan siswa yang bersekolah di sekolah full day. Ratarata prestasi belajar siswa reguler adalah 8,5867 sedangkan siswa full day school adalah 8,3685. Standar deviasi prestasi belajar siswa reguler adalah 0,8168 dan untuk 
siswa full day school adalah 0,82243. Standar error mean prestasi belajar siswa reguler adalah 0,06809 dan untuk siswa full day school adalah 0,07636.

Tabel 3. Output Kedua Hasil Analisis Uji Independent Sample T-Test Independent Sample Test

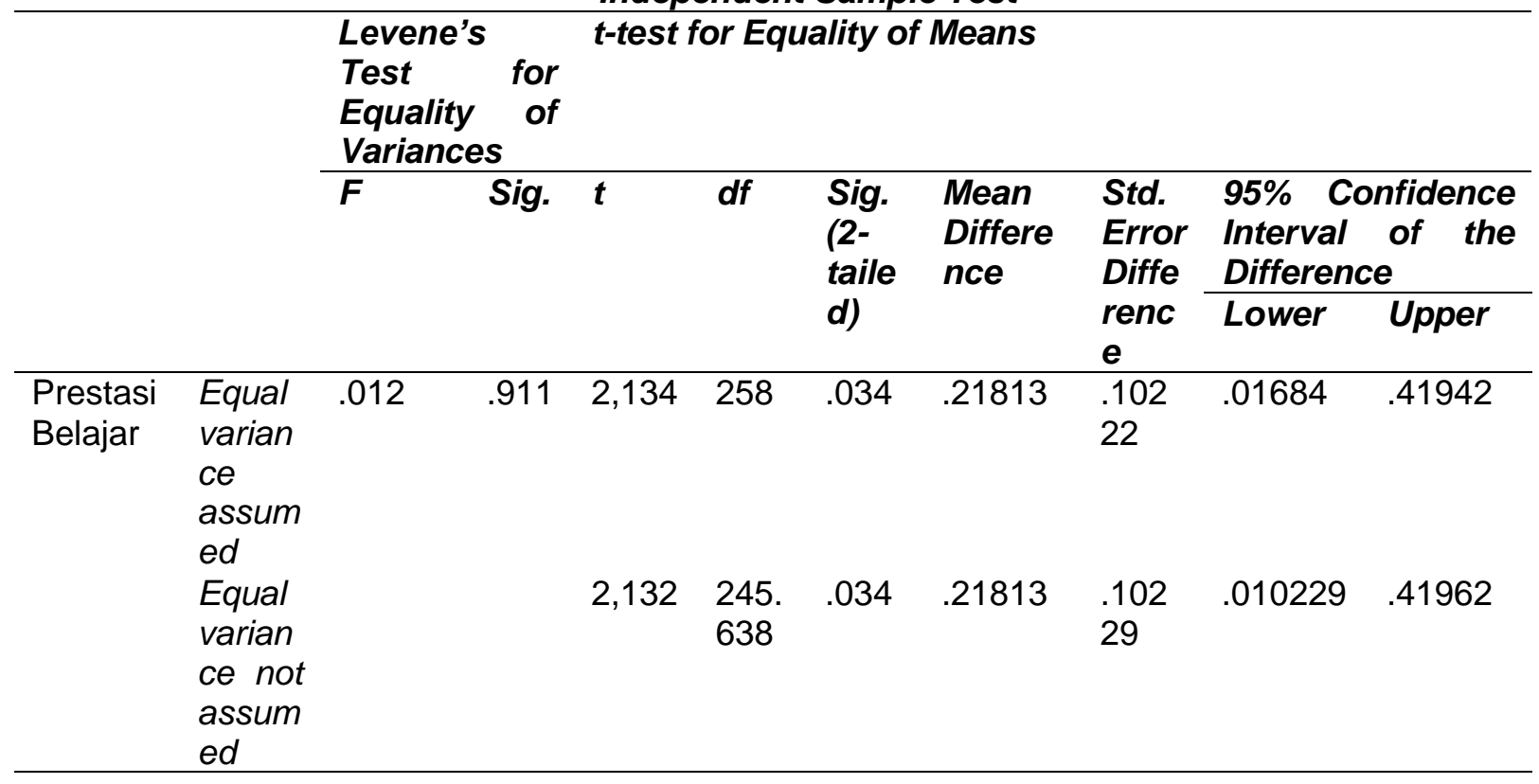

Output ini menjelaskan tentang hasil uji levene's (uji homogenitas) dan independent sample t-test yang digunakan untuk mengetahui tentang perbedaan prestasi belajar antara siswa kelas IV yang bersekolah di sekolah dengan sistem reguler dengan siswa yang bersekolah di sekolah dengan sistem full day school. Dari output di atas, didapatkan nilai signifikansi sebesar 0,034 sehingga dapat dinyatakan bahwa $0,000<0,05$. Karena signifikansi kurang dari 0,05, maka kesimpulannya adalah ada perbedaan prestasi belajar siswa kelas IV sekolah dasar antara siswa reguler dan siswa full day school serta salah satu sistem sekolah dasar tersebut memberikan pengaruh yang lebih baik terhadap prestasi belajar.

\section{Perbedaan Prestasi Belajar antara siswa sistem reguler dan sistem full day school}

Berdasarkan hasil pengujian hipotesis menggunakan aplikasi Statistical Product and Serice Solution (SPSS) versi 16 didapatkan hasil nilai Sig. (2 tailed) sebesar 0,034. Nilai Sig. (2 tailed) tersebut $<\alpha(0,05)$. Oleh karena itu, dapat diketahui bahwa ada perbedaan prestasi belajar siswa full day school dan siswa reguler. Pada output pertama hasil pengujian hipotesis didapatkan jumlah siswa reguler yaitu 36 dengan data sejumlah 144 dengan rata-rata nilai prestasi belajar siswa 8,5867, sedangkan jumlah siswa full day school yaitu 29 dengan data sejumlah 116 dengan rata-rata prestasi belajar siswa 8,3685. Selisih dari kedua rata-rata tersebut yaitu 0,2182. Ratarata prestasi belajar siswa reguler lebih tinggi dibandingkan dengan rata-rata prestasi belajar siswa full day school sehingga hipotesis penelitian ini dapat diterima. Oleh karena itu, dapat disimpulkan bahwa sekolah dengan sistem reguler memberikan pengaruh yang lebih baik terhadap prestasi belajar siswa kelas IV SDN se-Kecamatan Kebumen tahun 2019/2020.

Hasil penelitian ini relevan dengan penelitian yang dilakukan oleh Irayasa, dkk (2018: 84) yang menyatakan bahwa terdapat perbedaan prestasi belajaar siswa reguler dengan full day school dengan perbandingan prestasi belajar siswa sekolah reguler lebih tinggi dari siswa sistem full day school, dengan nilai rata 72,24 dan 88,16 pada sekolah regular. Penelitian lain yang sesuai dengan penelitian ini dikemukakan oleh Parameswari (2013: 9) bahwa siswa yang berasal dari TK reguler memiliki 
prestasi belajar yang lebih tinggi dibandingkan siswa yang berasal dari TK full day. Dalam penelitian ini nilai rata-rata pada semester satu untuk siswa reguler lebih tinggi yakni 87,60 sedangkan pada siswa full day school 87,23. Pada semester 2 rata-rata prestasi belajar siswa reguler adalah 88.90 sedangkan siswa full day school yakni 87,70 . Dalam penelitian ini dikatakan tidak ada perbedaan secara signifikan akan tetapi prestasi siswa reguler lebih unggul dibanding siswa full day school. Faktor yang menyebabkan siswa reguler memiliki prestasi belajar lebih tinggi adalah dari segi waktu belajar, sesuai dengan pendapat Rafoth dalam Parameswari (2013: 7) yang mengemukakan bahwa siswa reguler memiliki nilai lebih tinggi karena waktu pulang lebih awal sehingga siswa mempunyai waktu lebih berkualitas dengan orang tua dan dapat melakukan kegiatan yang lebih bermanfaat.

Penelitian ini juga relevan dengan penelitian Nafilasari dan Darminto (2020: 522) mengenai perbedaan burnout pada siswa full day school dan non full day school di Surabaya. Hasil penelitian menunjukkan perbedaan rerata skor non full day school 77,7 sedangkan siswa full day school memiliki rerata skor 69,6. Siswa non full day school (reguler) memiliki rerata skor yang lebih tinggi dibandingkan dengan rerata skor siswa full day school dikarenakan siswa full day school mengalami burnout lebih tinggi dibanding siswa non full day school. Burnout ini disebabkan oleh waktu belajar siswa full day school lebih lama yakni 8 jam dan cenderung memiliki tingkat kejenuhan yang lebih tinggi pula. Penelitian lain yang mendukung adalah penelitian oleh Mutakbir (2019: 74) yang menyatakan bahwa tingkat kejenuhan siswa non full day school berada pada kategori rendah dibanding dengan siswa full day school. Hal ini disebabkan karena siswa full day school mengalami keletihan dalam belajar sehingga tidak memiliki motivasi belajar, padahal motivasi itu sangat penting dalam kegiatan pembelajaran dan akan mempengaruhi tingkat prestasi belajar siswa. Selain lama waktu belajar, kejenuhan, keletihan dan kurangnya motivasi belajar, hal lain yang dapat mendukung hasil penelitian ini adalah stress akademik. Stress akademik adalah stress yang muncul terkait tuntutan akademik dalam pembelajaran yang dapat mempengaruhi tingkat prestasi siswa di sekolah. Hal ini sesuai dengan penelitian oleh Kusuma, Rachmah, \& Dewi (2018) mengenai perbedaan stress akademik siswa full day dan non full day di MAN Tanah Bumbu dan MAN 3 Banjarmasin dengan hasil penelitian yang menyatakan bahwa stress akademik pada siswa full day school lebih tinggi dari pada stress akademik pada siswa sekolah reguler, (Kusuma, Rachmah, \& Dewi, 2018: 61).

Hasil penelitian ini juga didukung dari hasil observasi pembelajaran antara sekolah reguler dengan full day school. Pembelajaran pada sekolah reguler tergolong dalam kriteria sangat baik untuk 2 pertemuan, sedangkan sekolah dengan sistem full day termasuk dalam kriteria baik untuk 2 pertemuan dan satu pertemuan awal termasuk kriteria cukup. Kualitas dalam pembelajaran ini dapat berpengaruh terhadap hasil prestasi belajar siswa khususnya dalam ranah kognitif.

Kesesuaian hasil penelitian ini dengan penelitian-penelitian sebelumnya membuktikan bahwa sistem sekolah memengaruhi prestasi belajar siswa dan sekolah reguler memberikan pengaruh yang lebih baik terhadap prestasi belajar dibandingkan dengan sekolah full day pada ranah kognitif. Berdasarkan analisis statistik yang dilakukan terhadap penelitian ini, diketahui rata-rata prestasi belajar siswa kelas IV sekolah dasar reguler adalah 8,5867, sedangkan rata-rata prestasi belajar siswa full day school adalah 8,3685. Hasil tersebut menunjukkan bahwa rata-rata prestasi belajar siswa reguler lebih tinggi dari rata-rata prestasi siswa full day school. Selain itu hasil dari thitung $(2,134)>t_{\text {tabel }}(1,6507)$ yang berarti bahwa terdapat perbedaan prestasi belajar antara siswa yang bersekolah di sekolah dengan sistem reguler dengan siswa sistem full day school kelas IV Sekolah Dasar tahun ajaran 2019/2020 di Kecamatan Kebumen adalah signifikan dan dapat diberlakukan untuk populasi. 


\section{SIMPULAN}

Berdasarkan hasil penelitian diperoleh simpulan bahwa ada perbedaan prestasi belajar antara siswa yang bersekolah di sekolah dengan sistem reguler dengan siswa sistem full day school kelas IV Sekolah Dasar tahun ajaran 2019/2020 di Kecamatan Kebumen. Hal tersebut ditunjukkan dengan nilai Sig. pada uji independent sample $t$ test yaitu 0,034 yang berarti bahwa nilai Sig. 0,000 < 0,05 (taraf $5 \%$ ) sehingga tolak $\mathrm{H}$ o. Rata-rata prestasi belajar siswa kelas IV sekolah dasar reguler adalah 8,5867, sedangkan rata-rata prestasi belajar siswa full day school adalah 8,3685. Berdasarkan hasil rata-rata tersebut, jenis sistem sekolah reguler memberikan pengaruh yang lebih baik terhadap prestasi belajar siswa kelas IV SDN se-Kecamatan Kebumen tahun 2019/2020.

\section{DAFTAR PUSTAKA}

Ernita, T., Fatimah., Adawiyah, R. (2016). Hubungan Cara Belajar Dengan Prestasi Belajar Siswa Dalam Mata Pelajaran PKn Pada Siswa Kelas X SMA Negeri 1 Banjarmasin. Jurnal Pendidikan Kewarganegaraan, Vol. 6 (11).

Irayasa, K., Alfian, I., Fitriana., Risma. (2018). Perbandingan Prestasi Belajar Siswa Sistem Full Day School dengan Sistem Reguler pada Mata Pelajaran IPA. Jurnal Nalar Pendidikan, 6 (2).

Kusuma, A.D., Rachmah, D.N., \& Dewi, R.S. (2018). Perbedaan Stress Akademik Pada Siswa yang Bersekolah Full Day dan yang Tidak Full Day di MAN Tanah Bumbu dan MAN 3 Banjarmasin. Jurnal Kognisia Vol. 1 (1).

Mukromah, D.S. (2017). Studi Komparasi Prestasi Belajar Mata Pelajaran IPS pada Sekolah Full Day School dan Reguler. Skripsi. Universitas Islam Negeri Maulana Malik Ibrahim Malang.

Muktabir. (2019). Perbandingan Tingkat Kejenuhan Peserta Didik Sekolah yang Menerapkan Full Day School dan Non Full Day School di Kabupaten Pangkep Provinsi Sulawesi Selatan. Skripsi UIN Alauddin Makassar.

Nafilasari, H.I., Darminto, E. (2020). Perbedaan Burnout Peserta Didik Pada Sekolah Menengah Full Day School dan Non Full Day. Jurnal BK UNESA Vol. 11 (4) .

Ngalimun., Fauzani, M., Salabi, A. (2016). Strategi dan Model Pembelajaran. Yogyakarta: Aswaja Pressindo.

Panji, A.K.D. (2016). Prestasi Belajar antara Siswa Program Khusus dan Reguler. Naskah Publikasi. Universitas Muhammadiyah Surakarta.

Parameswari, A. (2013). Studi Komparasi Prestasi Belajar Siswa Kelas Satu Sekolah Dasar Program Full-Day yang Berasal dari Taman Kanak-Kanak Program FullDay dan Reguler. Naskah Publikasi Universitas Muhammadiyah Surakarta.

Sari, D.M. (2018). Pengaruh Program Full Day School Terhadap Prestasi Belajar Siswa (Studi pada Siswa-Siswi Kelas XI di SMA Global Madani, Rajabasa, Bandar Lampung). Skripsi Universitas Lampung.

Syam, S. (2017, 14 Juni). Ini Dampak Buruk Full Day School. Pojok Satu.id. Diunduh dari: https://pojoksatu.id/pendidikan/2017/06/14/dampak-buruk-full-day-school/.

Winarni, B. (2015). Pengaruh Penerapan Full Day School Terhadap Kedisiplinan Siswa MI Muhammadiyah PK Kartasura Tahun Ajaran 2014/2015. Artikel Publikasi Ilmiah, Universitas Muhammadiyah Surakarta. 